\title{
CCLXXV. VITAMIN E DEFICIENCY IN THE RAT
}

\section{FERTILITY IN THE FEMALE}

\author{
BY MARY MARGARET OGILVY BARRIE \\ From the Physiological Laboratories of The British Drug Houses, Ltd., \\ London, $N .1$
}

(Received 28 October 1938)

THE consumption of a diet free from vitamin $\mathbf{E}$ produces sterility both in the male and in the female rat. In the male the sperms become non-motile and this is followed by degeneration of the testes. The condition in the male is not reversible and cannot be cured by administration of vitamin $\mathbf{E}$ once the degenerative phase has been reached [Evans, 1925; Mason, 1926; Evans \& Burr, 1927]. In the female it has generally been accepted that ovulation, fertilization and implantation remain normal, but pregnancy cannot be carried to term unless the animal is given an adequate dose of vitamin $\mathrm{E}$ on mating.

Bacharach et al. [1937] and Bacharach \& Allchorne [1938] observed that the incidence of fertile matings among vitamin E-deficient rats was very much lower in those which had undergone a resorption-gestation than in virgin animals; they concluded that the process of resorption left some permanent damage to the reproductive system but made no histological examination. Martin \& Moore [1936] reported the brown appearance of the uterus of rats fed on a vitamin E-deficient diet. Evans [1928] found that the incidence of spontaneous deciduomata of the uterus was much higher in vitamin E-deficient than in normal females.

In this laboratory it has been found that when vitamin E-deficient rats are mated with normal males and a vaginal plug is formed, this mating is almost invariably followed by implantation. I have found no apparent difference between virgin and resorbed animals in this respect. I do, however, find that among vitamin E-free animals, whether virgin or resorbed, more than half do not mate or else no plug is formed. It has also been found, in agreement with Bacharach, that animals which have once resorbed require a larger dose of vitamin $E$ to prevent resorption in the next gestation than their litter-mate virgin sisters of the same age.

A post-mortem examination has been made of rats which have been used for vitamin $\mathrm{E}$ experimental work and it has been found, without exception, that every rat which has undergone a resorption-gestation has a brown or yellowbrown uterus and ovaries containing large corpora lutea. Histological examination of the uterus reveals occasional patches of fatty degeneration in both the longitudinal and circular muscle coats. Deposits of red-brown pigment are found throughout the muscle layers. ${ }^{1}$ Many fibres are degenerated and packed with granules of pigment. These findings account for the discoloration of the uterus. There is often some fibrous tissue in the muscle layers, particularly in the older rats.

1 Since the completion of this paper Martin \& Moore have described the finding of granules of pigment in the uterine muscle of their vitamin E-deficient rats (Chem. \& Ind. 15 Oct. 1938). 
A number of virgin animals which had been fed on the vitamin E-free diet for different periods of time have been killed and examined post mortem. From these examinations it has been found that similar changes take place in virgin, vitamin E-free rats, but that resorption greatly accelerates their onset. Table I

\begin{tabular}{|c|c|c|c|}
\hline \multirow[b]{2}{*}{$\begin{array}{l}\text { No. } \\
\text { of } \\
\text { rats }\end{array}$} & \multirow[b]{2}{*}{$\begin{array}{l}\text { Months on } \\
\text { vitamin E- } \\
\text { free diet }\end{array}$} & \multicolumn{2}{|r|}{ Table I } \\
\hline & & History & Appearance of uterus \\
\hline & 4 & 1 resorption & $\begin{array}{l}\text { Pale yellow; } 1 \text { animal had } \\
\text { small fibroid }\end{array}$ \\
\hline 4 & 4 & Virgin & $\begin{array}{l}\text { Thread-like, very pale yel- } \\
\text { low; } 1 \text { brownish-yellow } \\
\text { and infected }\end{array}$ \\
\hline 5 & 5 & 1 resorption & $\begin{array}{l}\text { Yellow-brown; } 1 \text { showed } \\
\text { some thickening }\end{array}$ \\
\hline 3 & 5 & Virgin & $\begin{array}{l}\text { Yellow-brown; } 2 \text { had fi- } \\
\text { broids and were bleeding }\end{array}$ \\
\hline 7 & 7 & $\begin{array}{l}1 \text { or more re- } \\
\text { sorptions }\end{array}$ & $\begin{array}{l}\text { Yellow-brown to dark } \\
\text { orange-brown, } 1 \text { infected }\end{array}$ \\
\hline 6 & 7 & Virgin & Yellow-brown \\
\hline 9 & 8 & $\begin{array}{l}1 \text { or more re- } \\
\text { sorptions }\end{array}$ & $\begin{array}{l}\text { Brown to dark brown; } 1 \\
\text { bleeding from fibroid, } 2 \\
\text { infected, } 3 \text { fibrosis; all en- } \\
\text { larged }\end{array}$ \\
\hline 5 & 8 & Virgin & $\begin{array}{l}\text { Pale orange-brown; } 1 \text { very } \\
\text { distended }\end{array}$ \\
\hline
\end{tabular}

Microscopic examination
of uterus
Some pigment in muscle
layers
Traces of pigment

Considerable amount of pigment

Considerable amount of pigment

Large amount of pigment

Less pigment than resorbed animals, no fibrosis

Large amount of pigment, extensive muscle degeneration

Pigmented, a number of pigmented and degenerated muscle fibres present; some fat and in one case mucosa oedematous

illustrates these points; it is composed from the records of 44 consecutive postmortem examinations. After 4 months on the diet there is a slight increase in the size of the uterus and definite, although slight, discoloration; after 5 months the discoloration and enlargement are more marked and the condition is severe after 6 months of vitamin $\mathrm{E}$ deficiency. The uterus of a rat which has been on the diet for 5 months and undergone a resorption-gestation shows more discoloration than that of a similar virgin animal. The amount of discoloration present was in each case comparable with the amount of pigment found on microscopic examination. The enlarged condition is not due to infection, although this may sometimes occur. Where there is no infection the enlargement is usually associated with fibrosis and thickening of the uterine wall. The infections which quite frequently occur are possibly due to the frequent vaginal examinations which are made, although every reasonable precaution is taken to avoid infecting the animal.

In view of the changes in the uterine muscle it is not surprising that vitamin E-deficient animals which have undergone a resorption-gestation require more vitamin $\mathbf{E}$ to enable them to produce a litter than similar animals which have not resorbed, and it can also be understood that if the uterine degeneration has proceeded far enough, pregnancy will be impossible. Table II illustrates these points. It will be seen that $0.35 \mathrm{ml}$. of a (diluted) vitamin $\mathrm{E}$ preparation was an inadequate dose for a virgin animal which had been on the vitamin E-free diet for 9 months, but $0.5 \mathrm{ml}$. produced a litter of 6 in a similar animal. $0.5 \mathrm{ml}$. was inadequate for animals of almost the same age which had undergone one or two resorptions respectively, yet $0.75 \mathrm{ml}$. produced a litter of 1 in an animal which 


\begin{tabular}{|c|c|c|c|c|c|}
\hline \multicolumn{6}{|c|}{ Table II } \\
\hline $\begin{array}{l}\text { Rat } \\
\text { no. }\end{array}$ & $\begin{array}{c}\text { Dose of } \\
\text { vitamin E } \\
\text { preparation } \\
\text { ml. }\end{array}$ & Result & $\begin{array}{l}\text { No. months } \\
\text { on vitamin } \\
\text { E-free } \\
\text { diet }\end{array}$ & $\begin{array}{l}\text { No. } \\
\text { resorption } \\
\text { gestations }\end{array}$ & Appearance of uterus \\
\hline 1272 & 0.35 & Litter of 5 & 5 & 1 & Slightly yellow \\
\hline 1136 & $0 \cdot 35$ & Litter of 2 & 8 & 0 & Not killed \\
\hline 1096 & $0 \cdot 35$ & $\begin{array}{l}\text { Litter of } 8 \\
\text { (dead in uterus) }\end{array}$ & 9 & 0 & 8 full-term dead foetuses removed \\
\hline 1022 & 0.50 & Litter of 6 & 9 & 0 & Small and brown \\
\hline 794 & $0 \cdot 50$ & Resorption & 10 & 1 & $\begin{array}{l}\text { Brown; signs of resorption of large } \\
\text { foetus }\end{array}$ \\
\hline 1033 & 0.50 & Resorption & 10 & 2 & Large and very brown \\
\hline 698 & 0.50 & Resorption & 11 & 1 & Large and very brown \\
\hline 1051 & $0 \cdot 75$ & Litter of 1 & 10 & 2 & Normal colour, very small \\
\hline 1032 & $0 \cdot 75$ & Resorption & 10 & 2 & Dark orange-brown \\
\hline
\end{tabular}

had had two resorption-gestations and been on the diet for 10 months, but failed to prevent resorption in an exactly similar animal. Since the $0.35 \mathrm{ml}$. dose was adequate for the 3 - and 4-months animals then $0.75 \mathrm{ml}$. is a relatively enormous dose and the fact that it failed to produce a litter in an animal which had received the vitamin E-deficient diet for 10 months and gave only a litter of one in another animal which had been on the diet for the same length of time, shows that after about 10 months of vitamin $\mathbf{E}$ deficiency female rats have reached or are very near the stage of irreversible sterility. On a normal diet a female rat is capable of producing living young until she is at least 18 months old. The normal colour of the uterus of the rat which had a litter of 1 following a dose of $0.75 \mathrm{ml}$. remains unexplained unless the large amount of the vitamin given exerted a curative effect on the degeneration. Investigation of this point is at present in progress.

The fact that fibrosis of the uterus often occurs in connexion with the discoloration has already been mentioned, but more advanced stages than this are regularly met with in this stock of vitamin E-deficient rats. Non-pregnant animals have occasionally been found bleeding from the vagina, the amount of blood lost being quite large in some cases. 30 cases of such bleeding have been observed in the last year and reference to Table I will give some idea of its incidence. These animals have been killed and the uterus has been found to have a series of rounded whitish enlargements separated by discoloured muscle. These masses are hard to cut and their inner surfaces are pearly white. On microscopic examination they are seen to consist of a mass of fibrous tissue and are typical fibromyomata.

It is, of course, quite possible that fibromyomata occur in rats fed on a normal diet, but the incidence among our stock must be very much less than among the vitamin E-deficient rats in this laboratory, because a post-mortem examination is made of all the stock animals which die or which are of no further use for breeding, and no tumour of this type has been found on microscopic examination. Similarly, these stock animals never develop uterine discoloration and even among those animals which are too old to bear litters no pigmentation or fatty degeneration of the uterus has been found. These observations are based on the records of our breeding stock for the last 2 years. This stock has been maintained at a level of approximately 150 females, 100 of which have been killed in the interval.

These observations raise several points. It is clearly important in assaying a substance for its vitamin $\mathbf{E}$ activity to make sure that the animals used have been 
fed on the vitamin E-deficient diet long enough to be sterile but not long enough to have developed uterine changes, and the onset of these degenerative changes must obviously vary between different stocks and depend to a great extent on the degree to which the diet is free from vitamin $\mathrm{E}$.

The statement that vitamin $\mathbf{E}$ deficiency is reversible in the female but not in the male is only partly true, because the deficiency is curable in both male and female rats if vitamin $\mathbf{E}$ is given early enough, but if the deficiency is allowed to proceed to testicular or advanced uterine degeneration, absolute sterility is produced in both sexes.

A more detailed study is being made of the incidence of the fibromyomata but this preliminary work indicates that in the rat they are associated with vitamin E deficiency.

\section{SUMMaRY}

The discoloration of the uterus described by Martin \& Moore in vitamin E-deficient rats has been confirmed.

This discoloration is caused by the deposition of a pigment in the muscle layers associated with degeneration of the muscle.

Prolonged vitamin E deficiency caused fibrosis of the uterine muscle; a certain number of the animals developed fibromyomata of the uterus.

I wish to express my thanks to Dr S. W. F. Underhill and Dr F. H. Carr for their helpful advice and to the Directors of The British Drug Houses Ltd. for permission to publish this work.

\section{REFERENCES}

Bacharach \& Allchorne (1938). Biochem. J. 32, 1298.

—— \& Glynn (1937). Biochem. J. 31, 2287.

Evans (1925). Proc. Nat. Acad. Sci. $2,373$.

— (1928). Amer. J. Physiol. 85, 149.

\& Burr (1927). Memoirs of Univ. California, 8.

Martin \& Moore (1936). Proc. Biochem. Soc., March 13th.

Mason (1926). J. exp. Zool. 45, 159. 